\title{
Selvmord i Arktis
}

\author{
Ved A rnt-O ve Eikeland
}

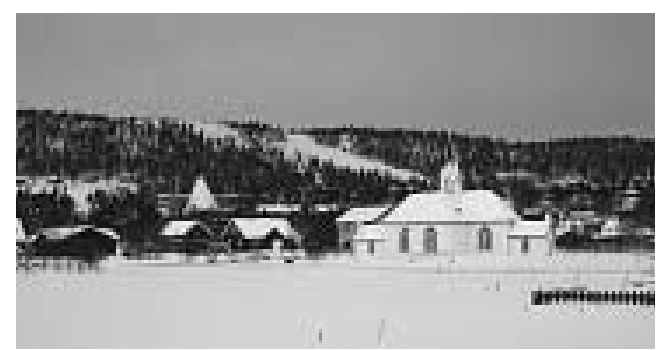

\begin{abstract}
Denne artikkelen er ment å gi innsikt i noen sider av arktisk selvmordsproblematikk. Arktiske strøk har de høyeste selumordsratene i verden. Undertegnede vokste opp i Karasjok, en samisk bygd i Finnmark huor det å ta sitt eget liv er en del av stedets historie.
\end{abstract}

\section{Innledning}

En sommerdag på midten av 80-tallet gjorde en ung gutt selvmord i Karasjok. $\mathrm{H}$ an var et aktet og høyt respektert medlem av ungdomsfellesskapet. Dette skulle bli begynnelsen på en bølge av selvmord dette stedet skulle bli rammet av. Totalt gjorde åtte mennesker selvmord i løpet av de to neste årene. D e fleste var gutter i tenårene. Det var gutter ingen forbandt med en slik type handling. De var ikke kjennetegnet ved psykisk ubalanse eller andre diagnoser det er vanlig, eller lett, å assosiere med problemet selvmord. De var som ungdommer flest, som man gjerne sier. Selvmordene kom derfor som lyn fra klar himmel. Besteforeldre, foreldre, søsken, venner og andre ble satt i en tilstand av sjokk og fikk en følel se av uvirkelighet. 0 mgivel sene ble fylt med angst og skyld, angst for det utenkelige og skyld for det man eventuelt kunne ha gjort for å forhindre det inntrufne.

Etter denne bølgen av selvmord roet det seg. Det ble ikke gjort noen selvmord de neste to årene. Det var imidlertid ikke slutt. Tre år etter bølgen begynner problematikken igjen. En unggutt ble funnet hengt ute i skogen. En voksen mann skjøt seg. En mor ble funnet død - man antok det var selvmord. Selvmord begynte å skje jevnt og trutt, og det var ikke lenger bare unge gutter som val gte å ta sitt eget liv. Det var snakk om hele spennet fra ung til gammel. D en yngste som tok sitt liv var 16 år, den eldste var godt over 50 år. Selvmordene kom fortsatt brått på. Ingen kunne forutse og forstå hvorfor akkurat disse menneskene tok sitt eget liv. Selvmord skjedde jevnt og trutt i årene som kom. Problematikken er fortsatt like aktuell $\mathrm{i}$ dag. $\mathrm{H}$ vert år er det minst en som bæres til graven som et resultat av selvmord. Totalt har det vært over 30 selvmord de siste 20 årene. Innbyggertallet i Karasjok har i hele perioden ligget i underkant av 2800 mennesker.

A lle disse selvmordene har vært entydige i den forstand at metodene har vært henging, skyting og forgiftning. Sosiolog og sel vmordsforsker Yngve H ammerlin kaller denne type virksomhet for døds- virksomhet. Døden har forrang, og målet for handlingen er å dø. I motsetning til dødsvirksomhet står livsvirksomhet. Livsvirksomhet er når livet har fortrinn, og er målet for den enkeltes handlinger. Karasjok har i tillegg opplevd en rekke selvmordsforsøk og tilfeller av voldsom død, gjerne forårsaket av hasardiøs omgang med kjøretøy hvor det er uklart om ulykken er arrangert eller ikke. $\mathrm{H}$ ammerlin kaller denne type handlinger for livstruende virksomhet. Det er en virksomhet hvor det individuelle målet for handlingen ikke nødvendigvis er egenskade.

\section{Arktisk problem}

$H$ vordan kunne og kan slike høye selvmordstall forekomme - på et lite sted som Karasjok? Det er ingen enkle forklaringer på slike spørsmål, men for å komme nærmere en forståelse vil det være av interesse å sette fenomenet inn i en større sammenheng. Det som skjedde og skjer i Karasjok er ikke unikt hvis vi ser dette i et arktisk perspektiv. Dette med høye selvmordstall og selvmordsbølger er også kjent fra andre strøk i A rktis, og det er flere trekk som går igjen i problematikken.

1) N oen landsbyer er hardt rammet, mens andre ikke har noen problemer med selvmord. Vi har sett at Karasjok har store problemer, mens nabobygda Kautokeino ikke har nevneverdige problemer. D et samme skjer på G rønland. Samfunn har opplevd at kanskje 4- 5 av bygdas gutter og unge menn har tatt sitt liv i løpet av fă uker (O Isen, 1998). Bygdene Kulusuk og Kuumiut på G rønlands østkyst har den høyeste forekomsten av selvmord i verden, mens andre grønlandske bygder og større steder derimot ikke har problemet.

2) De fleste som tar sitt liv er ikke psykiatriske pasienter, men tilsynelatende helt normale, vanlige borgere. Det er i tillegg en taushet med i bildet ( $\mathrm{H}$ ammerlin \& Schjelderup, 1994:26). Sel vmordene skjer oftest uten at det er gitt noe forvarsel. Dette gjør det vanskelig for hjel peapparatet å treffe nødvendige forebyggen de tiltak og å gripe inn ovenfor potensielle kandidater. $\mathrm{H}$ ammerlin snakker om usynlige og synlige sel vmordskandidater. De usynlige er de som ikke har markert eller varslet selvmordshensikter, men som likevel kan leve i et mørke om dagen ( $\mathrm{H}$ ammerlin \& Schjelderup, 1994; C hristiansen, 1990).

3) Det er grunnlag for å snakke om copycat-effekt. En form for smitteeffekt kunne man også kalle det. I den forbindelse er det naturlig å tenke på boken $D$ en unge W erthers lidelser (1774) av G oethe, som utløste en bølge av selvmord blant studenter på 1800-tallet. I Karasjok startet selvmordsbølgen med at en ung gutt hengte seg. D ette utl øste en rekke andre selvmord. Det som er verd å merke seg er at de fire første som gjorde selvmord, var svært nære venner. De var det vi kan kalle bestekompiser. De andre som døde i løpet av disse to hektiske årene, var mer perifere når det gjaldt vennskap.

\section{Handlingskulturer}

A rktiske områder er kjennetegnet ved enorme arealer og liten befolkning. Sibir, A laska, N ord-C anada, G rønland og N ord$\mathrm{N}$ orge er slike områder som ligger på "toppen av kloden". Befolkningen er ofte situert i små landsbyer som ligger langt fra hverandre. A rktiske områder er befolket av urfolksgrupper som samer, inuitter, komi, nenetsere og flere. D ette er urfolksgrupper som har bebodd disse områdene i uminnelige tider, og har sitt eget språk, kultur og historie. U rfolksgruppene har derimot ikke landrettigheter og selvbestemmel se. Disse gruppene står dermed i et minoritetsforhold eller -posisjon til majoriteten i de respektive land de bor i. De må kjempe for at deres kultur ikke skal bli "visket" ut gjennom bevisst og ubevisst påvirkning fra majoritetsbefolkningen. Spørsmål av politisk, språklig og kulturell art oppstår derfor ofte i dette minoritets/majoritetsforholdet.

U rfolk i A rktis kjører bil og snøscooter, bor i hus, har politistasjon, kirke og skole, er på Internett, ser på TV osv. Det kan virke som det gamle levemønsteret er visket ut, men man skal ikke være lenge i disse samfunnene før man ser at de gamle tradisjonene lever under overflaten og 

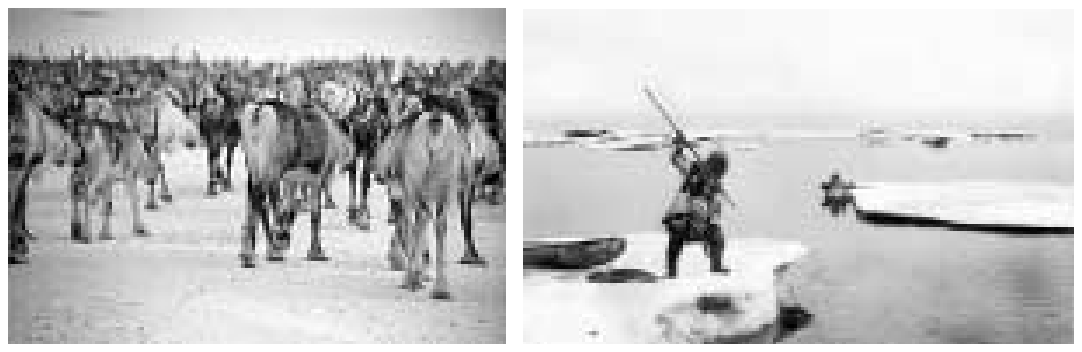

holdes ved like. $M$ ange av disse arktiske samfunn hvor urfolk er i flertall, er derfor sterkt preget av å være "gammeldagse" eller tradisjonelle.

De fleste menneskene som bor i disse områdene, har et sterkt forhold til naturen og det den byr på gjennom blant annet jakt og fiske. U tviklingen mot det moderne har gått svært fort for de arktiske urfolk. Fra i hovedsak å være folk som hadde tilpasset sitt levesett til næringer som det var muligå drive i den arktiske natur, har utviklingen gått mot en mer moderne måte å leve på. D e tradisjonelle næringer har jevnt over vært vanskelige å til passe den moderne tid og dens krav til effektivitet. Det som før var næringer som var tilpasset den skjøre naturen, er nå næringer som må oppfylle krav til økonomisk bærekraft. Disse utfordringene har man ikke på langt nær klart å mestre. A rktiske urfolk kan derfor sies å være i "spennet" mellom tradisjon og modernitet. Dette har spesiell betydning for de unge i disse samfunnene, og får for eksempel konsekvenser $\mathrm{i}$ forhold til spørsmål om utdannelse. $M$ ange ser ikke betydningen av skolegang. I denne sammenheng betyr det at mange har problemer med å tilpasse seg de krav som stilles til ungdom i et moderne liberalt demokrati, hvor teoretisk viten gjennom skolegang ofte er en forutsetning for å lykkes på arbeidsmarkedet. Konsekvensen er at mange ungdommer avslutter skolegangen og foretrekker å drive med tradisjonelle og praktiske næringer. Det kan for eksempel være reindrift og selfangst. $M$ ange foretrekker å lære et håndverk gjennom erfaring uten å gå veien om skolegang. De unge lærer seg å reparere snøscootere, biler, motorsykler osv. uten å ha noen formell utdannelse som grunnlag. Kunnskap om disse næringene og ulike håndverk tilegner de seg gjennom erfaring og bruk av gjenstander. De elærer detaljer om redskaper, de ser hvordan kunnskapen skal brukes i praksis, gjerne gjennom prøving og feiling. Lærdommen kan derfor sieså være kontekstuell. Den er ikke knyttet opp til teori. Tromsøfilosofen Viggo Rossvær kaller dette for vantmann-kunnskap (Rossvær, 1998).

Disse hăndverk er også en uttrykksform. De arktiske kulturer har vært mye basert på redskaper og kunnskap utviklet i samspill med det harde klimaet. Det lever derfor et eksistensielt behov for å utrykke seg gjennom redskaper. N år praktisk kunnskap er så høyt prioritert, er en naturlig konsekvens at mange ikke reiser ut fra stedet hvor de er født og vokst opp. Spesielt gutter har en tendens til å prioritere slik. Denne effekten kan bli forsterket av at de voksne heller ikke ser betydningen av en formell utdannelse. Det er derfor liten tradisjon for akademisk liv i disse områdene. D e fleste kan skrive og lese, men det blir ikke alltid verdsatt høyt å lese bøker. Det betyr ikke at vi har med analfabeter å gjøre, men med prioriteringer. Prioriteringer som er knyttet opp til et liv hvor verdiene finnesi en kultur hvor den teoretiske skoleviten ikke er grunnvollen. Det blir også et spørsmål om identitet. H va man gjør, er med på å bestemme hvem man er. Ved å beherske tingene gjennom erfaring eller gjøren - blir den enkelte vurdert av de andre. D et er snakk om en handlingskultur hvor det å leve er å utrykke seg gjennom å handle, en handlingskultur hvor det å gjøre ting er med å på bestemme og utrykke identiteten til den enkelte. Den enkelte får mye av sin identitet gjennom det vedkommende har valgt å gjøre. Jeg blir til gjennom hva jeg velger å gjøre. Det kan derfor sies at det er på grunnlag av valg og beslutninger selvet dukker opp. Det blir gjerne referert til hendel ser knyttet til yrker og andre virksomheter når en person skal omtales.

\section{Historiefortellingens betydning}

$\mathrm{N}$ år handlinger og valg blir så viktige, er også formidlingen av hva som har blitt valgt viktig og dette skjer gjennom språket. Det er i språket at verdensbildene

og selvbildene gjemmer seg og kommer til uttrykk, og det er i språket de kan avdekkes og tolkes. For å avdekke sider av den enkeltes væren i verden må man se på hvordan språket til aktørene brukes. H vordan aktørene er i verden, kommer til utrykk gjennom språkbruk. H andlingskulturens språk er ikke uttrykt i teoretiske og akademiske vendinger, men i historiefortelling. Historiefortellingen er essensiell i mange henseende for å forstå forholdet mellom identitet, valg og handling i A rktis. H vis en person har val gt å utføre en handling, som for eksempel å passere en råk på scooter på en måte som oppfattes som heroisk, kan denne personen bli gjenstand for historiefortelling. $M$ ange gjør derfor grenseoverskridende handlinger for å bli en helt $\mathrm{i}$ en historie. De beste historiene lever gjennom generasjoner. Det er ikke uvanlig å høre om bravadene som skjedde langt tilbake i tid. De blir fortalt så levende at man skulle trodd de akkurat hadde skjedd. Den involverte vet at det vil bli historier ut av det. Det gjelder derfor å vel ge å gjøre handlinger som setter spor etter seg.

Jeg forutsetter at mennesket er et vesen som søker mening i sin tilværelse. I A rktis er mening, handlingskulturer og historiefortelling intimt forbundet.

\section{Det heroiske selvmord}

$\mathrm{H}$ vordan kan handlingskultur og en muntlig tradisjon knyttes opp til bølger av selvmord i A rktis? I Karasjok erfarte jeg at det under bølgen var tvetydige reaksjoner på alle selvmordene. De fleste reagerte med forferdel se og sorg, men mange reagerte også annerledes. $M$ ange unge jenter hadde bilder av de døde guttene på veggen på pikerommet. De døde guttene ble heller ikke fordømt av sine jevnaldrende, men nesten beundret og sett opp til. Dette kom senere til utrykk i historier. Disse historiene er på mange måter "heltehistorier" om hvor sterke og fryktIøse disse guttene var. I kke engang døden skremte dem. De hadde ingen grenser.

De var døde, men levde videre i historiene. Historiene bar mer preg av respekt og beundring en $n$ fordømmelse og sorg. Dette kan ha vært en drivkraft til at så mange valgte å ta sitt eget liv. $H$ andlingen selvmord under bølgen kan derfor ha blitt oppfattet som en meningsfull handling ved tanken på å bli evig i en historie.

Det kan på dette grunnlag ha dreid seg om en form for lengsel etter å bli historie. $\mathrm{N}$ år en slik lengsel blir sterk nok, er kanskje - ikke lenger døden noe å frykte? $M$ ange av menneskene som gjorde selvmord i Karasjok, kan knyttes opp til kategorien handlingsmennesker. De var unge gutter som aldri kunne tenkt seg å reise fra Karasjok - og som heller aldri tok noen formell utdannelse etter grunnskolen.

$M$ ange av de samme strukturelle trekkene finner vi igjen i andre arktiske strøk, som en sterk integrasjon, et lavt utdanningsnivå, handlingskulturer og en sterk fortellertradisjon. 
Det heroiske sel vmordet er også kjent fra U ngarn, hvor det ikke nødvendigvis blir sett på som noe ynkelig å ta sitt eget liv ( $\mathrm{H}$ ammerlin \& Schjelderup, 1994: 50). Det at selvmordet ikke bare kan knyttes opp til skam, fordømmelse og depresjon er det mange historiske eksempler på. U nder 2. verdenskrig ble de japanske kamikazeflyvere kjent. De var selvmordsflyvere som bevisst gikk inn for å styrte jagerflyene sine inn i skip fra den amerikanske flåte. Det var neppe på grunn av depresjon de gjorde det. A I-Q aida medlemmene som fløy inn i tvillingtårnene i W orld Trade C entre 11. september 2001 er et annet eksempel. Det er bedre å dø med ære enn å leve med skam. I bakgrunnen ligger forestillingen om evig liv i enten den japanske versjonen av Valhall, eller for A I-Q uida i det muslimske paradis. Den vestlige rasjonalitet har ikke mye å stille opp med i kampen mot slike forestillinger (Brøgger, 2004). Den allmenne lærdommen av slike historiske eksempler er at selvmordet ikke bare kan knyttes opp til depresjon slik det er en tendens til i vestlig tenkning. Selvmordet kan ha å gjøre med grunner som ære, styrke og heroisme. (The European, 1993)

Det kan virke paradoksalt at et menneske kan sikre sin posisjon ved å gjøre selvmord. Selvmordet er likevel en måte å sette spor etter seg i verden på. A lle har behov for å bli husket. Brå død blir ikke glemt. Forfatteren $\AA$ smund Brynhildsen er inne på noe når han beskriver sel vmordets kompleksitet: "Tro ikke at selvmordet ber om en glemsel: Det ber om evig erindring." Disse betraktningene viser utover det rent psykologiske og mot noe dypt allmennmenneskelig: Behovet for å sette spor etter seg i verden.

\section{Avslutning}

I denne artikkelen har jeg forsøkt å få frem sider ved hva som kjennetegner arktisk sel vmordsproblematikk. U tgangspunktet var å unngå å redusere selvmordet til bare et utrykk for sykdom eller avvik (H ammerlin \& Schjelderup, 1994). Dette skyldes at jeg ut fra mine erfaringer og min videre forskning vanskelig kan se at det tjener saken å overlate denne problematikken ene og alene til medisinen.

Vi har mulighet til å styre livet vårt i stor grad - nemlig med holdningen vi velger å ha til livet. J eg går derfor imot forkla- ringer som reduserer selvmordet til enten bare biologi, psykologi eller sosiologi. $0 \mathrm{~m}$ selvmordet er sykdom eller en allmennmenneskelig mulighet, er det ingen gitte svar på. I et forebyggingsperspektiv bør likevel begge perspektivene kunne

\section{diskuteres.}

Forebygging er den beste beskyttelse mot selvmord. Skal man forebygge, må man imidlertid først finne de viktigste årsakene til et problem og så forsøke å gjøre noe med disse årsakene. Det er viktig å avdekke de forhold som skaper mistrivsel og lidelse - og de som skaper gode og trygge livsvilkår for mennesker. Dette betyr verken at all selvmordsforebygging skal ligge kun i psykisk helsevern eller at behandlingsapparatet har sviktet hver gang det skjer et selvmord. D et ville være urettferdig ovenfor behandlings-/hjel peapparatet hvis all skyld og ansvar skulle tillegges dem. $\mathrm{H}$ vis allmennheten, leger og andre eksperter får mer kunnskap om det kulturelle grunnlaget for mye av det som fortoner seg som naturlig og selvfølgelig, kan mange politiske og sosiale problemer unngåes. En for skarp forenkling av årsakene til de høye selvmordtal lene i mange arktiske landsbyer, uten i tilstrekkelig grad å ta hensyn til det mangfold, den variasjon og gjensidige påvirkning som de ulike faktorene har, kan føre til fatale feils sutninger. Jeg har forsøkt å vise at mye av selvmordsproblematikken i Karasjok, og i andre arktiske landsbyer, handler om depressive reaksjoner fremkalt av ytre omstendigheter og hendel ser, og at det ikke er snakk om varige indre tilstander. Derfor bør det gjøres grundige tverrfagl ige studier som tar for seg de problemer og utfordringer urfolk møter $i$ sin tilnærming til blant annet modernitetens krav til hva det vil si å være menneske.

Den vestlige medisin har vært en suksess, særlig den naturvitenskapelige, teknologiske siden av den, men det som er gått tapt underveis, er det humanistiske perpektivet. Der gjelder andre ressurser; forståelse og fortolkning av hele mennesket. A lle som jobber med helse, bør en gang iblant spørre seg hva et menneske er. Det kan godt være at de ikke har tenkt igjennom en del ting som både er nyttige og viktige.

Det har vært dyptgripende kulturelle endringer i synet på selvmord i Vesten (Leer-Salvesen, 2004). Tidligere ble selv- morderen møtt med moralsk fordømmelse, mens vedkommende i dag blir møtt med forståelse og empati, og selvmordstanker er noe som kan behandles og kureres.

Depresjon er nok den vanligste årsak til selvmord i Vesten i dag. A ntidepressiver er et flott hjelpemiddel, med det kurerer ikke et meningsproblem. A ntidepressiver er derfor alene ikke en god løsning. D et er et allment trekk ved det å være menneske at vi ikke alltid kan være lykkelige. G rå stunder og tunge dager er en del av livet, og det må vi vanligvis kunne kurere på annen måte enn den kjemiske eller ved å bli pasienter i behandlingssystemet. $\mathrm{H}$ vis vi bare bruker psykisk sykdom som forklaring på selvmord blant ungdom og andre $i$ arktiske strøk, kan det få folk til å tro at de ikke kan gjøre noe for å forhindre noen i å ta sitt eget liv. Det kan være med på å forføre folk til å betvile sin egen moralske og verdimessige kapasitet. Selvmordet utspiller seg i rommet mellom individet og de andre, og dette rommet bør alltid inneholde etisk refleksjon og etiske valg (Leer-Salvesen, 2004). $0 \mathrm{~g}$ i dette rommet opererer vi alle.

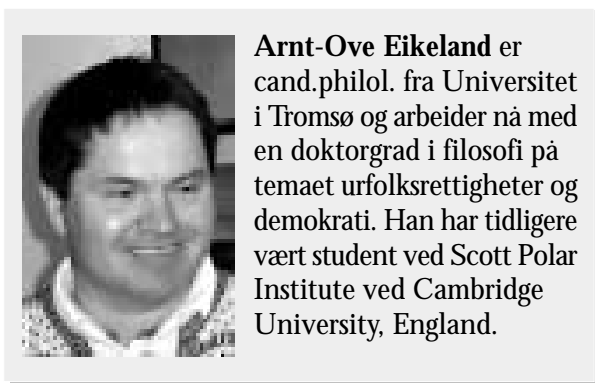

\section{Referanser}

Brøgger, Jan. (2004, 20. februar). D e som velger døden. Kronikk i A ftenposten.

Christiansen, Ing-Britt. (1990). D e "uforståelige" ungdomsselvmord i G rønland: En kulturel analyse. Specialrække nr. 32, Institut for antropologi, Københavns U niversitet.

Hammerlin, Yngve \& Schelderup, Georg. (1994). $\mathbf{N}$ år livet blir en byrde. 0 slo: $G$ yldendal.

Leer-Salvesen, Paul. (2004). D rap og selvmord en etisk refleksjon. Suicidologi, 9(1), 13-15.

O dner, Knut. (1995). Samisk identitet. N orsk A ntropologisk Tidsskrift, 6(2). [127]-138, [173].

O Isen, Terje. (1998, 1. oktober). G rønland - bare selvmord og fyll? K ronikk i Dagbladet .

Rossvær, Viggo. (1998). R uinlandskap og modernitet. Sparctatus.

W here suicide is still nobel. (1993, 18. oktober). A rtikkel i The European. 